\title{
Smoking at home is strongly associated with symptoms of asthma and rhinitis in children of primary school age in Trinidad and Tobago
}

\author{
Michele A. Monteil,, ${ }^{1}$ Gina Joseph, ${ }^{1}$ Catherine Chang Kit, ${ }^{1}$ Gillian Wheeler, ${ }^{2}$ \\ and Robin M. Antoine ${ }^{3}$
}

Suggested citation

Monteil MA, Joseph G, Chang Kit C, Wheeler G, Antoine RM. Smoking at home is strongly associated with symptoms of asthma and rhinitis in children of primary school age in Trinidad and Tobago. Rev Panam Salud Publica. 2004;16(3):193-8.

ABSTRACT Objective. To compare, in the twin-island republic of Trinidad and Tobago, the prevalence of symptoms of asthma and rhinitis among children of primary school age who are exposed to household environmental tobacco smoke with the prevalence of these symptoms in their colleagues without this exposure.

Methods. Between September and December 2002, questionnaires based on the instrument developed for the International Study of Asthma and Allergies in Childhood (ISAAC) were distributed, via the children in their schools, to parents of 6611 Year 2 pupils (typically 6 years old) or Year 3 pupils (typically 7 years old) in 106 randomly selected schools in Trinidad and Tobago (5 511 pupils on Trinidad and 1100 pupils on Tobago). We added to the standard ISAAC questionnaires two questions, one on household smoking and one on the ethnicity of the children.

Results. A total of 3170 completed questionnaires were suitable for further analysis (2 618 from Trinidad and 552 from Tobago). On Trinidad 782 of the children (29.9\%) lived in homes where one or both parents smoked, and $513(19.6 \%)$ had other relatives in the household who smoked. On Tobago 94 of the pupils (17.0\%) had parents who smoked, and 84 (15.4\%) came from homes where other residents smoked. Parental smoking was significantly associated with wheezing (odds ratio (OR): 1.43; 95\% confidence interval (CI): 1.11-1.83), exercise-induced wheezing (OR: 2.12; 95\% CI: 1.59-2.82), nocturnal coughing (OR: 1.64; 95\% CI: 1.37-1.97), and symptoms of rhinitis (OR: 1.35; 95\% CI: 1.10-1.65) in the last 12 months as well as a history of hay fever/sinus problems (OR: 1.39; 95\% CI: 1.11-1.74). Smoking in the home by adult residents other than parents was also significantly associated with all of these symptoms as well as a history of asthma (OR: 1.49; 95\% CI: 1.13-1.97). In terms of ethnic differences, parental smoking was most prevalent in the homes of South Asian students, while smoking by other adults in the home occurred most commonly in the households of pupils of mixed race.

Conclusions. Even in Trinidad and Tobago, which is a tropical environment where more time is spent outdoors and homes have more open ventilation than in temperate climates, environmental tobacco smoke exposure is closely associated with an increased prevalence of symptoms of asthma and rhinitis in primary-school-aged children.

Key words Asthma, rhinitis, tobacco smoke pollution, child, Trinidad and Tobago.

University of the West Indies, Faculty of Medical Sciences-St. Augustine Campus, Champs Fleurs, Trinidad. Send correspondence to Michele Monteil, Department of Para-Clinical Sciences, Faculty of
Medical Sciences, Eric Williams Medical Sciences Complex, Uriah Butler Highway, Champs Fleurs, Trinidad; telephone: (868) 663-6987 or (868) 683-1352; fax: (868) 663-3797; e-mail: mmonteil@tstt.net.tt
Scarborough General Hospital, Scarborough, Tobago. University of the West Indies, Faculty of Science and Agriculture, Department of Mathematics and Computer Science, St. Augustine, Trinidad. 
The global burden of allergic disease has increased in the past 30 years, and disorders such as allergic asthma have reached epidemic proportions. This is especially true of the disease in the pediatric population, where asthma is one of the most common chronic disorders. Since the prevalence of allergic diseases varies both around the world (1) and in different regions of the same country, there has been interest in environmental factors that may influence the development of these disorders and the exacerbation of preexisting disease. One environmental exposure that has been linked to the development and exacerbation of asthma in childhood is tobacco smoke.

Environmental tobacco smoke (ETS) is considered the most important indoor pollutant associated with pediatric asthma (2). It has been shown that the earlier the exposure and the longer the duration of exposure to tobacco smoke, the greater the likelihood for the development of asthma and other respiratory symptoms (2). ETS is also associated with more frequent respiratory infections in children as well as exacerbation of asthma.

Parental smoking has been shown to be associated with more frequent exacerbation and more severe symptoms in children with asthma (3), and there is evidence to suggest that each additional smoker in the household increases the risk for asthma or wheezing in children (4). It has even been shown that occasional exposure to ETS, as may occur with regular visits to other relatives who smoke or with visits by adolescents to clubs and discotheques, can result in an adverse effect on lung function (5).

Environmental exposure to tobacco smoke has also been implicated in nasal and sinus dysfunction. In a review on the effects of ETS on nasal and sinus disease, Benninger asserted that ETS exposure in both adults and children is associated with acute and chronic nasal symptoms as well as snoring in children and adolescents (6).

A nationwide study of allergic diseases in children attending primary or secondary school was recently conducted in the twin-island republic of
Trinidad and Tobago. ${ }^{4}$ The study showed that the prevalence of wheezing among pupils 6-7 years old in the country was $12.4 \%$, with $9.5 \%$ having a previous diagnosis of asthma. Since the overall prevalence of adult smoking in Trinidad and Tobago is $25.1 \%$ (7), it is possible that household exposure to tobacco smoke may be an important trigger of symptoms of asthma and rhinitis in children in the country. Moreover, if exposure to tobacco smoke in the home is associated with an increased prevalence and severity of symptoms of asthma and rhinitis in those children, then educational efforts directed at their parents and guardians on the dangers of household smoking could lead to significant reductions in the children's morbidity from these diseases. Therefore, we hypothesized that Trinidadian and Tobagonian primary-school-aged children exposed to ETS had a higher prevalence of symptoms consistent with asthma and rhinitis compared to other, comparable children who were not exposed to tobacco smoke in the home. To our knowledge, this study is the first to try to determine if ETS is associated with symptoms of asthma and rhinitis in the pediatric population of Trinidad and Tobago.

\section{METHODOLOGY}

\section{Study design and study instrument}

For our nationwide questionnaire survey, we used a computerized database that our research team had created of all the public and private primary schools in Trinidad and Tobago. The SPSS version 9.0 statistical program (SPSS Inc., Chicago, Illinois, United States of America) was used to generate a random selection of $20 \%$ of those schools. In the order in which they had

\footnotetext{
4 Monteil MA, Joseph G, Chang Kit C, Siung-Chang A, Wheeler G, McIntosh D, et al. Smoking at home is strongly associated with symptoms of asthma and rhinitis in school-aged children in Trinidad and Tobago. Presentation at the Trinidad \& Tobago Medical Association 9th Medical Research Conference, 12 October 2003, Port-of-Spain, Trinidad.
}

been selected, the schools were approached to solicit their involvement in the project. Of the 85 schools that had been selected on Trinidad, 82 of them (96.5\%) participated; on Tobago, 20 of $21(95.2 \%)$ participated.

The questionnaire instrument was based on the one developed for global use by the International Study of Asthma and Allergies in Childhood (ISAAC) (8). To the "core" ISAAC questions we added two questions related to home environmental tobacco exposure: (1) Do you [mother, father of the school child] smoke cigarettes at present? (2) Do other persons that live in your home smoke cigarettes? The ethnicity of the children was assessed by asking their parents to state if the children were one of the following; African (black), Caucasian (white), South Asian (Indian), Chinese, Mixed, or Other. Information on participants' racial ancestry was obtained, since there have been reports elsewhere of racial differences in asthma prevalence and severity (9), and we wanted to determine if such differences exist in the multiethnic population of Trinidad and Tobago.

The questionnaires were sent to the parents and guardians via the pupils in the selected schools. The students were in either Year 2 or Year 3 of primary school. Children in Trinidad and Tobago begin primary school at 4 years of age, so that students in Year 2 are typically 6 years of age and the pupils in Year 3 are usually 7 years of age.

All students in these classes were eligible for participation, and the students were given the questionnaire to take home to their parents. In total, 5511 questionnaires were distributed on Trinidad and 1100 on Tobago. The completed forms were retrieved from schools within one to two weeks of distribution. Teachers were asked to encourage nonresponding parents to complete questionnaires and return them. When possible, we returned to schools a further one to two weeks later to collect forms that were returned late. The responses were entered into a computerized database using Access software (Microsoft Professional 2000, Microsoft Corporation, Redmond, Washington, United States). 


\section{Outcome measures}

The primary outcome measures were the prevalence of symptoms of wheeze and rhinitis in the 12 months prior to the study. In this study, as in other ISAAC surveys, symptoms of wheeze are considered synonymous with asthma in this age group. Similarly, symptoms of sneezing or of runny or blocked nose in the absence of a "flu" are considered synonymous with allergic rhinitis. Caregivers were asked in the "core" questionnaire to say whether or not their children had wheezing or whistling in the chest in the last 12 months and whether or not their children had a problem with sneezing, a runny nose, or a blocked nose when he/she did not have a cold or flu. Parents and guardians were also asked to say if their children had exercise-induced wheezing and nocturnal coughing and whether there had been a previous diagnosis of asthma or rhinitis.

\section{Statistical analysis}

In this study we compared the prevalences of symptoms of asthma and rhinitis in children exposed to ETS with the prevalence levels among those not exposed to ETS. Data were analyzed with the SPSS version 9.0 statistical package. The chi-square $\left(\chi^{2}\right)$ test was used to compare the prevalence of the symptoms, while the significance of the odds ratios (ORs) was assessed with 95\% confidence intervals (CIs).

\section{Ethical approval}

The survey was conducted between September and December 2002, following its approval by the Ethics Committee of the Faculty of Medical Sciences, University of the West Indies-St. Augustine Campus. Since parents were asked to fill out the questionnaire on behalf of their children, a covering letter stating clearly the purpose of the research was provided with each questionnaire. Parents and guardians were also assured that their participation was entirely optional.

\section{RESULTS}

\section{Response rates}

Completed questionnaires were retrieved from 102 of the 106 schools that had agreed to participate in the survey. Of the 5511 questionnaires distributed to primary school children on Trinidad, 2631 questionnaires were retrieved, and 2618 of them had full responses (response rate, $47.5 \%$ ). On Tobago, 1100 questionnaires were distributed and 559 were retrieved. Of these, 552 had been completed (response rate, $50.2 \%$ ).

\section{Demographic analysis of children}

The male to female ratio among the study participants, 1.03:1.00, was the same on both islands. However, there were marked differences between the ethnicities of the Trinidadian children and of the Tobagonian children, as reported by their parents. In the Trinidadian sample $38.7 \%$ of the children were South Asian, 30.6\% mixed, 27.7\% African, and $0.5 \%$ Caucasian; $1.0 \%$ of the students were reported as being of "other" ethnicity, and there were no responses for $1.5 \%$. On Tobago there was a predominance of students of African ethnicity (86.0\%), along with $11.4 \%$ mixed, $1.4 \%$ South Asian, 0.5\% other, and $0.7 \%$ for whom there was no response.

\section{Prevalence of smoking}

On Trinidad 782 of the 2618 children $(29.9 \%)$ lived in homes where one or both parents smoked, and 513 of them $(19.6 \%)$ lived in homes where other residents smoked. On Tobago 94 of the 552 students (17.0\%) had parents who smoked, and $84(15.2 \%)$ reported smoking by other residents of the home.

In the country as a whole, there were significant differences $\left(\chi^{2}, P<\right.$
0.0001) in the prevalence of smoking among the parents of the children of different ethnicities. Smoking was most prevalent among the parents of the South Asian pupils (33.6\%), versus parents of mixed race students $(29.7 \%)$ and of African students (22.3\%). Statistically significant differences in the children's ethnicity $\left(\chi^{2}, P<0.0001\right)$ were also found in the prevalence of smoking among other occupants of the children's homes. Smoking by other residents of the home was most common in the homes of pupils of mixed race $(25.0 \%)$, versus students of South Asian descent (17.3\%) or of African descent $(17.0 \%)$.

\section{Prevalence of asthma and rhinitis symptoms in relation to exposure to cigarette smoke in the home}

The prevalences of symptoms of wheeze, exercise-induced wheeze, nocturnal cough, and sneezing, runny nose, or blocked nose in the 12 months prior to the survey were all statistically greater in children who were exposed to parental cigarette smoke in the home (Table 1) or to nonparental cigarette smoke in the home (Table 2). A diagnosis of hay fever was also significantly more common among children exposed to smoking in the home. In children with a previous history of asthma there was a statistically significant association with nonparental smoking.

\section{DISCUSSION}

The response rate of approximately $50 \%$ from parents was disappointing. Nevertheless, over 3100 responses were available for analysis, and this represents approximately $2 \%$ of the total primary school population of Trinidad and Tobago. Our cohort of participants is similar in gender and age distribution to that described for the entire primary school population of Trinidad and Tobago (10). The ethnic differences that we found in the study groups on the two islands generally reflect the racial differences that 
TABLE 1. Comparison of the prevalence of symptoms of asthma or rhinitis among primary school children either exposed to or not exposed to parental cigarette smoking in the home, with odds ratio (OR) and 95\% confidence interval (Cl), Trinidad and Tobago, 2002

\begin{tabular}{|c|c|c|c|c|c|c|c|}
\hline \multirow[b]{2}{*}{ Symptom/diagnosis } & \multicolumn{2}{|c|}{ Exposed } & \multicolumn{2}{|c|}{ Not exposed } & \multirow[b]{2}{*}{ OR } & \multirow[b]{2}{*}{$95 \% \mathrm{Cl}$} & \multirow{2}{*}{$\begin{array}{l}P \text { value } \\
\left(\chi^{2} \text { test }\right)\end{array}$} \\
\hline & No. & $\%$ & No. & $\%$ & & & \\
\hline Wheezing in the last 12 months & 1186 & 37.4 & 929 & 29.3 & 1.43 & $1.11-1.83$ & 0.004 \\
\hline Nocturnal coughing in the past 12 months & 904 & 28.5 & 628 & 19.8 & 1.64 & $1.37-1.97$ & 0.0001 \\
\hline Sneezing, runny nose, or blocked nose in last 12 months & 1369 & 43.2 & 1160 & 36.6 & 1.35 & $1.10-1.65$ & 0.004 \\
\hline Diagnosis of asthma & 358 & 11.3 & 301 & 9.5 & 1.25 & $0.96-1.62$ & 0.107 \\
\hline
\end{tabular}

exist between the overall population of Trinidad and that of Tobago. However, the ethnic composition of the study participants on Trinidad differed from the reported ethnic composition of this island (11). On Trinidad there were more respondents whose children were of South Asian or mixed ethnicity and fewer whose children were of African heritage than is true for the general population. One possible explanation for this may be that parents from the first two ethnic groups were more willing to respond to the questionnaire.

The general low rate of response was in part due to the relative lack of interest of some schools in the project and the relative lack of interest by parents in either completing the questionnaire or ensuring that it was returned to their children's teacher. Teachers in a few rural schools also told the researchers that a few parents had some difficulty in completing the questionnaires because of their limited reading skills.
The overall prevalence of parental smoking in the two islands that we found in our study $(23.5 \%)$ was very similar to the reported national average $(25.1 \%)(8)$. Our results indicated that smoking was more common among parents of children of South Asian or mixed ethnicity. Smoking by other members of the household occurred more frequently in households with children of mixed heritage. We are unaware of any existing study on the racial differences in the smoking habits of Trinidadians and Tobagonians, and so we can make no comparisons with studies specifically designed to determine the characteristics of smokers in Trinidad and Tobago. Therefore, we are unable to fully exclude the possibility of socioeconomic differences among these races and hence the ability to purchase cigarettes and other forms of tobacco. According to a nationwide household budgetary survey that was conducted between May 1997 and May 1998, the average monthly income for households in which the head of the household was of mixed ethnicity was TT\$ 5169 (US\$ 834), versus TT\$ 4253 (US\$ 686) where the head of the household was of Indian descent and TT\$ 4151 (US\$ 670) where the head of the household was of African heritage (11).

Parental smoking was strongly associated with symptoms of wheeze, exercise-induced wheeze, nocturnal coughing, symptoms of rhinitis, and a diagnosis of hay fever or sinus problems. There was no statistically significant relationship between parental smoking and a previous history of asthma, though the difference was significant for exposure to nonparental smoking. The higher prevalence of symptoms suggestive of asthma in primary-school-aged children in Trinidad and Tobago living in households with ETS is similar to findings reported from other parts of the world. In her review of indoor pollution and childhood asthma (3), Etzel summarized the earlier findings of Burchfiel and colleagues, who had conducted a questionnaire survey in the town of

TABLE 2. Comparison of the prevalence of symptoms of asthma or rhinitis among primary school children either exposed to or not exposed to nonparental cigarette smoking in the home, with odds ratio (OR) and 95\% confidence interval (Cl), Trinidad and Tobago, 2002

\begin{tabular}{|c|c|c|c|c|c|c|c|}
\hline \multirow[b]{2}{*}{ Symptom/diagnosis } & \multicolumn{2}{|c|}{ Exposed } & \multicolumn{2}{|c|}{ Not exposed } & \multirow[b]{2}{*}{ OR } & \multirow[b]{2}{*}{$95 \% \mathrm{Cl}$} & \multirow{2}{*}{$\begin{array}{l}P \text { value } \\
\left(\chi^{2} \text { test }\right)\end{array}$} \\
\hline & No. & $\%$ & No. & $\%$ & & & \\
\hline Wheezing in the last 12 months & 1249 & 39.4 & 948 & 29.9 & 1.61 & $1.23-2.11$ & 0.002 \\
\hline Exercise-induced wheezing in the last 12 months & 301 & 9.5 & 203 & 6.4 & 1.61 & $1.17-2.22$ & 0.004 \\
\hline Nocturnal coughing in the past 12 months & 957 & 30.2 & 644 & 20.3 & 1.72 & $1.41-2.11$ & 0.0001 \\
\hline Sneezing, runny nose, or blocked nose in last 12 months & 1474 & 46.5 & 1167 & 36.8 & 1.5 & $1.13-2.00$ & 0.007 \\
\hline Diagnosis of asthma & 412 & 13.0 & 301 & 9.5 & 1.49 & $1.13-1.97$ & 0.015 \\
\hline Diagnosis of hay fever/sinus problems & 571 & 18.0 & 415 & 13.1 & 1.46 & $1.14-1.87$ & 0.004 \\
\hline
\end{tabular}


Tecumseh, Michigan, United States of America. The study by Burchfiel and colleagues reported an odds ratio of 1.7 in boys and 1.2 in girls for the development of asthma following ETS exposure. The Tecumseh results were independent of parental respiratory illnesses, parental education, family size, and age (3).

Our findings differ from those of other studies that have reported a significant association between ETS exposure and a diagnosis of asthma. Even in Puerto Rico, another tropical Caribbean island, Beckett and colleagues reported the presence of a cigarette smoker in the household as an important risk factor for the development of childhood asthma (12). In our study, while there was a statistically significant association between a previous history of asthma in the primary school children and smoking by persons other than the parents in the household, this significance was not found with exposure to parental smoking. Smoking in Trinidad and Tobago is far more common among adult men $(42.1 \%)$ than it is among adult women (8.0\%) (7). As a result there is relatively little maternal smoking, which is the form of parental smoking most strongly associated with the development of asthma (4). It is also possible that the prevalence of previous asthma has been underestimated in our study. In young children, as in this study group, asthma may present as nocturnal coughing, so-called "cough-variant asthma." In our survey, $22.7 \%$ of the children on Trinidad and $17.4 \%$ of the children on Tobago reported nocturnal cough in the absence of a cold or chest infection. However, only $10.1 \%$ and $8.8 \%$, respectively, reported previous asthma. It is therefore possible that some children with nocturnal cough do in fact have undiagnosed asthma.

This questionnaire study did not include questions about other possible outdoor or indoor environmental irritants, so we cannot comment on potential confounding pollutants. Some well-defined sources of indoor pollutants, such as heating with gas, coal, kerosene units, and fireplaces as well as cooking on wood- or coal-burning stoves (13), are unimportant in the tropical islands of Trinidad and Tobago. Further, houses in Trinidad and Tobago tend to be well ventilated, and with relatively few homes having air conditioning or carpeting.

Another limitation of our questionnaire approach is that there was no independent corroboration of asthma or rhinitis by physical examination or ancillary tests such as lung function testing. However, the ISAAC questionnaire has been validated in relation to bronchial hyperreactivity (14) and doctor-diagnosed asthma (15).

Our report has highlighted the significant associations between parental and nonparental smoking and symptoms of asthma and rhinitis in young children in Trinidad and Tobago. The similarity in the results for exposure to either parental or nonparental smoking may reflect the extended family structure that is common in Trinidad and Tobago, in which elderly grandparents or uncles or aunts may be residents of the home. In these situ- ations, children are just as likely to be exposed to nonparental smoking as to parental smoking. It may even be argued that since smoking is far more common among male Trinidadians, a child is more likely to have more exposure to ETS from a retired grandfather who lives at the child's home and smokes than from the child's own father, who is working during the day.

We believe that cessation or reduction of passive ETS exposure may lead to a decrease in the symptoms that we found in children, and the associated morbidity. We also believe that an aggressive education campaign aimed at reducing parental and nonparental smoking in the home is urgently needed to lessen the morbidity from the effects of tobacco smoke in children in Trinidad and Tobago and possibly also lessen demands on our already overstretched health care services.

Acknowledgements. This project was commissioned by the Environmental Management Authority of Trinidad and Tobago and was funded through a Pan American Health Organization (PAHO) grant to Michele Monteil. The authors wish to thank the following persons for their assistance with this project: Owen Cuffie, project chauffeur; Avril Siung Chang, PAHO Office, Trinidad and Tobago; D. MacIntosh and Wayne Rajkumar, Environmental Management Authority; the Ministry of Education of Trinidad and Tobago; the Tobago House of Assembly, Education Desk; the Health Education Unit, Tobago; and the principals and students of all the participating schools.

\section{REFERENCES}

1. International Study of Asthma and Allergies in Childhood (ISAAC) Steering Committee. Worldwide variation in prevalence of symptoms of asthma, allergic rhinoconjunctivitis and atopic eczema. Lancet. 1998;351:1225-32.

2. Becker A. Environmental control and immunotherapy. In: FitzGerald JM, Ernst P, Boulet L-P, O'Byrne PM, eds. Evidence-based asthma management. Hamilton: BC Decker Publishers; 2001. Pp.169-82.
3. Etzel RA. Indoor air pollution and childhood asthma: effective environmental interventions. Environ Health Perspect. 1995;103 Suppl 6:55-8.

4. Ehrlich RI, Du Toit D, Jordaan E, Zwarenstein M, Potter P, Volmink JA, et al. Risk factors for childhood asthma and wheezing: importance of maternal and household smoking. Am J Resp Crit Care Med. 1996;154(3):681-8.

5. Giuseppe MC, Agabiti N, Forastiere F, Dell'Orco V, Pistelli R, Kriebel D, et al. Lung function in children and adolescents with occasional exposure to environmental tobacco smoke. Am J Resp Crit Care Med. 1996;154(3): 695-700.

6. Benninger MS. The impact of cigarette smoking and environmental tobacco smoke on nasal and sinus disease: a review of the literature. Am J Rhinol. 1999;13(6):435-8.

7. World Health Organization. The tobacco atlas 2002. Available from: http://www.who.int/ 
tobacco/statistics/tobacco_atlas. Accessed 3 November 2003.

8. ISAAC Steering Committee and ISAAC Phase Three Study Group. ISAAC phase three manual. Auckland: ISAAC; 2000.

9. Aligne CA, Auinger P, Byrd RS, Weitzman M. Risk factors for paediatric asthma. Contributions of poverty, race and urban residence. Am J Respir Crit Care. 2000; 162:873-7.

10. Trinidad and Tobago, Ministry of Planning \& Development Central Statistical Office. Report on education statistics 2000/2001. Portof-Spain: CSO; 2003.

11. Trinidad and Tobago, Central Statistical Office. Central Statistical Office [Web site].
Available from: http://www.cso.gov.tt. Accessed 5 November 2003.

12. Beckett WS, Belanger K, Gent JF, Holford TR, Leaderer BP. Asthma among Puerto Rican Hispanics: a multi-ethnic comparison study of risk factors. Am J Resp Crit Care Med. 1996; 154(4):894-9.

13. United States, National Institutes of Health, National Heart, Lung, and Blood Institute. Global initiative for asthma: global strategy for asthma management and prevention. Bethesda: Department of Health and Human Services, Public Health Service; 2002. (NIH Publication No. 02-3659).
14. Shaw R, Woodman K, Ayson M, Dibdin S, Winkelmann R, Crane J, et al. Measuring the prevalence of bronchial hyper-responsiveness in children. Int J Epidemiol. 1995;24:597-602.

15. Jenkins MA, Clarke JR, Carlin JB, Robertson CF, Hopper JL, Dalton MF, et al. Validation of questionnaire and bronchial hyperresponsiveness against respiratory physician assessment in the diagnosis of asthma. Int J Epidemiol. 1996;25:609-16.

Manuscript received 24 December 2003. Revised manuscript accepted for publication on 14 July 2003.

RESUMEN Objetivo. Comparar, en las dos islas que integran la república de Trinidad y Tabago, la prevalencia de síntomas de asma y de rinitis en escolares de primaria expuestos al humo de tabaco en el ambiente domiciliario con la prevalencia de los mismos síntomas en coetáneos sin la exposición.

\section{Asociación entre fumar dentro de la casa y síntomas de asma y de rinitis en escolares de primaria en Trinidad y Tabago}

Métodos. Entre septiembre y diciembre de 2002, se distribuyeron cuestionarios basados en el instrumento elaborado para el Estudio Internacional de Asma y Alergias en la Niñez (ISAAC, por International Study of Asthma and Allergies in Childhood). La distribución la efectuaron los escolares de 106 escuelas escogidas aleatoriamente en Trinidad y Tabago (5 511 escolares en Trinidad y 1100 en Tabago) entre los padres de 6611 escolares de segundo o tercer grado (por lo general de 6 y 7 años de edad, respectivamente). Añadimos dos preguntas al cuestionario ISAAC, una de ellas sobre el tabaquismo en el domicilio y la otra sobre el origen étnico de los niños.

Resultados. Un total de 3170 cuestionarios llenados se prestaron a análisis (2 618 de Trinidad y 552 de Tabago). En Trinidad 782 (29,9\%) de los niños vivían en hogares donde uno de los padres o ambos padres fumaban, y 513 (19,6\%) tenían otros parientes en el domicilio que fumaban. En Tabago 94 de los niños $(17,0 \%)$ tenían padres que fumaban y $84(15,4 \%)$ venían de hogares donde otros residentes fumaban. El tabaquismo en los padres mostró una asociación significativa con la presencia de sibilancias (razón de posibilidades [RP]: 1,43; intervalo de confianza de 95\% [IC95\%]: 1,111,83), sibilancias provocadas por el ejercicio (RP: 2,12; IC95\%: 1,59-2,82), tos nocturna (RP: 1,64; IC95\%: 1,37-1,97) y síntomas de rinitis (RP: 1,35; IC95\%: 1,10-1,65) en los 12 meses más recientes, así como antecedentes de fiebre del heno o problemas sinusales (RP: 1,39; IC95\%: 1,11-1,74). La presencia en el domicilio de parientes fumadores distintos de los padres también mostró una asociación significativa con todos estos síntomas y con antecedentes de asma (RP: 1,49; IC95\%: 1,13-1,97). En cuanto a diferencias por razones étnicas, el tabaquismo de los padres fue más frecuente en los hogares de escolares del sur del Asia, mientras que el tabaquismo de otros adultos en el domicilio se observó con más frecuencia en los hogares de escolares de raza mixta.

Conclusiones. Aun en Trinidad y Tabago, que se ubica en un ambiente tropical donde se pasa más tiempo al aire libre y donde las viviendas tienen mejor ventilación que en climas templados, la exposición a humo de tabaco en el ambiente se asocia estrechamente con una prevalencia aumentada de síntomas de asma y rinitis en escolares de primaria. 